\title{
The Effect of Hypothermia on Electric Impedance and Penetration of Substances from the CSF into the Periventricular Brain Tissue
}

\author{
IGOR KLATZO, CHOH-LUH LI, DONM. LONG, ANTHONYF.BAK, MIROSLAW \\ J. MOSSAKOWSKI, LEVON O. PARKER AND LOIS E. RASMUSSEN
}

Branch of Surgical Neurology, National Institute of Neurological Diseases and Blindness, National Institutes of Health, Public Health Service, Department of Health, Education and Welfare, Bethesda, Maryland 20014 (USA)

\section{INTRODUCTION}

Lowering the temperature of the brain can affect it in either a beneficial or an adverse manner. The ability of mild hypothermia to reduce brain volume has been extensively used by neurosurgeons in alleviating increased intracranial pressure and cerebral edema. On the other hand, a number of adverse effects have been reported following cooling of the brain below $28^{\circ} \mathrm{C}$. At these temperatures numerous clinical complications (such as cerebral edema or hypoxic brain injury) and experimental disturbances (such as a breakdown of the blood-brain barrier) have been reported (Brendel et al., 1966). A further elucidation of the basic changes due to lowering brain temperature appears to be of considerable importance.

Hypothermia causes an increase in the electric impedance of brain tissue in the rabbit (Collewijn and Schade, 1962, 1964). This increase was thought to be a result of changed physical properties of the tissue since a similar change was found in electrolyte solutions at corresponding temperatures (Collewijn and Schadé, 1962).

Recently a series of experiments were designed in our laboratory (Li et al., 1966) for the study of physiological changes in the brain under hypothermia. These experiments show that impedance changes recorded from the grey matter at temperatures above $20^{\circ} \mathrm{C}$ were in accordance with temperature coefficients of the blood serum and $\mathrm{NaCl}$ solution. Below this temperature, the changes were greater than those recorded from serum and electrolyte fiuid. These observations probably reflect changes in the electrolyte and extracellular compartments, as has been reported to occur in asphyxia (Van Harreveld, 1957).

It was then conjectured that alteration in such basic properties of nervous parenchyma should influence penetration of various substances from the cerebrospinal fluid (CSF) (Davson and Spaziani, 1962). After crossing the ependymal barrier the substances can migrate further in several ways. Generally, the inert, extracellular compounds, such as inulin, may spread primarily by passive diffusion through extra- 
cellular spaces (Rall et al., 1962), whereas, an active transport mechanism has been implicated in penetration of diverse substances such as histamine (Draskoci et al., 1960), amino acids (Lajtha, 1962; Levin et al., 1966), and albumin (Klatzo et al., 1964).

The purpose of the present study is to correlate some of the electrophysiological data obtained after brain cooling with observations on periventricular penetration of substances, selected for their association with either diffusion or active transport.

\section{Materials and Methods}

For the study of electric impedance changes, 35 cats under Fluothane anesthesia and extracorporeal hypothermia were used. The temperature and the blood flow in the brain were regulated by extracorporeal circuits connected with the common carotid arteries. This method is similar to that described by Kristiansen et al. (1960) and will be reported in a separate communication (Ohta et al., 1966). In brief, the blood flow through the carotid artery was constant at a rate of $7.3 \mathrm{ml} / \mathrm{kg} / \mathrm{min}$ and the temperature of the cerebral hemisphere was gradually lowered to $13-12^{\circ} \mathrm{C}$. The perfusion pressure was continuously measured at the entry of the extracorporeal catheter into the carotid and the general systemic blood pressure was taken from the abdominal aorta. Temperatures of various structures of the brain and of the rectum were likewise continuously recorded. Before, during, and towards the end of the cooling experiment blood samples were obtained from the abdominal aorta for determination of $P_{\mathrm{CO}_{2}}, P_{\mathrm{O}_{2}}$ and $\mathrm{pH}$. Syuare pulses of low intensity current were applied through two $\mathrm{Ag}-\mathrm{AgCl}$ electrodes across the brain while recordings were made with two microelectrodes in the tissue. The difference of potential recorded was taken as a measure of impedance between the two recording electrodes. These electrodes were also capable of recording membrane resting potentials and action potentials of the brain tissue. Impedance changes at various temperatures were also measured in $0.9 \% \mathrm{NaCl}$ solution and cat's blood serum.

Observations on passage of various substances from the CSF into the periventricular brain tissue were carried out on 20 cats using ventriculo-cisternal perfusion. Palmer's intraventricular cannula was introduced into the right lateral ventricle through an opening located $8 \mathrm{~mm}$ from the midline and $5 \mathrm{~mm}$ posterior to the fronto-parietal suture. An outflow needle was inserted into the cisterna magna. An adjustable flow rotary pump was used to regulate the rate of flow through a polyethylene tube connecting the intraventricular cannula with a reservoir of perfusing fluid. The latter consisted of Elliott's fluid containing one of the radioactive substances and sodium fluorescein which was used as a standard marker for comparison. The radioactive compounds and their concentrations in the perfusing fluid were as follows: (1) 0.014 $\mathrm{mM}\left[{ }^{14} \mathrm{C}\right]$ inulin ${ }^{1}$, specific activity $2.7 \mathrm{mC} \mathrm{gm}$; (2) $0.201 \mathrm{mM}\left[{ }^{14} \mathrm{C}\right]$ sucrose $^{2}$, specific activity $9.0 \mathrm{mC} / \mathrm{mM}$; (3) $0.0009 \mathrm{mM}\left[{ }^{14} \mathrm{C}\right] \mathrm{L}$-leucine ${ }^{3}$ with specific activity $34.1 \mathrm{mC}$ $\mathrm{mM}$. In each case approximately $210 \mu \mathrm{C}$ of the individual radioactive tracer in mixture

\footnotetext{
1 New England Nuclear Corp., Boston, Mass.

2 Intern. Chem. and Nuclear Co., Los Angeles, Calif.

3 Tracerlab, Waltham, Mass.
} 
with sodium fluorescein was perfused for $45 \mathrm{~min}$ at the rate of $0.15 \mathrm{ml} / \mathrm{min}$. Following passage of the tracers the ventricular system was rinsed for $10 \mathrm{~min}$ at the same perfusion rate with Elliott's fluid after which the animals were sacrificed by rapid exsanguination. In hypothermic animals the ventriculo-cisternal perfusion was started about $30 \mathrm{~min}$ following the onset of cooling when the brain temperature had been lowered to approximately $15^{\circ} \mathrm{C}$. In this hypothermic group, 5 cats were perfused with $\left[{ }^{14} \mathrm{C}\right]$ inulin, 3 with $\left[{ }^{14} \mathrm{C}\right]$ sucrose and 2 with $\left[{ }^{14} \mathrm{C}\right] \mathrm{L}$-leucine. An equal number of animals were perfused with the same tracers at the normal body temperature. Following the sacrifice, the brains were immediately removed and a standard coronal block at the level of lateral ventricles, corpus callosum and putamen was rapidly frozen on a metal holder. From this tissue $10 \mu$ sections were cut in the cryostat. Using a previously described (Steinwall and Klatzo 1966) double tracer technique it was possible to compare individually in the same section the areas of penetration of sodium fluorescein and the distribution of the radioactive tracers by subjecting single sections consecutively to photography under the U.V. light and radioautography.

For assessment of the ultrastructural effects of these manipulations the following procedure was utilized. Three cats underwent brain cooling to $15-12^{\circ} \mathrm{C}$, ventricular perfusion with Elliott's solution for $55 \mathrm{~min}$, and then were fixed by direct carotid perfusion with $1000 \mathrm{ml} 2.5 \%$ glutaraldehyde in a $440 \mathrm{mM}$ phosphate buffer at the same flow rate as utilized in the blood perfusion. Three animals were similarly fixed at normal body temperature after undergoing only ventricular perfusion. Following fixation the tissue was diced $(1 \times 1 \mathrm{~mm})$, exposed to $1 \%$ osmium in the same buffer for one hour, and then embedded in epon according to standard technique.

\section{RESULTS}

The time course of the change in temperature of the cerebral hemisphere under investigation was almost identical in all experiments as shown in Fig. 1. In about $28 \mathrm{~min}$ the temperature dropped from $36-34^{\circ} \mathrm{C}$ to $15^{\circ} \mathrm{C}$ and, thereafter, was maintained at a level of $13-12^{\circ} \mathrm{C}$.

Measurements of perfusion pressure, systemic arterial pressure, $P_{\mathrm{O}_{2}}, P_{\mathrm{CO}_{2}}$ and $\mathrm{pH}$ at various temperatures obtained from different animals were found to be similar. Fig. 2 shows the average values of these measurements. In all cases the oxygen tension in the blood was increased with a decrease of brain temperature. It is to be noted that the body temperature as taken from the rectum ranged between 31 and $30^{\circ} \mathrm{C}$ while the brain temperature was $15-12^{\circ} \mathrm{C}$. If the increase in $P_{\mathrm{O}_{2}}$ is due to a decrease in oxygen consumption of the body tissue as a result of hypothermia, the decrease must have been more marked in the cooled cerebral tissue than in other tissues. In any case, there was no indication of hypoxia in any of these animals.

During the cooling procedures resting membrane potentials were measured from 87 polarized elements in the cortex of the cooled hemisphere. At temperatures above $17^{\circ} \mathrm{C}, 60 \%$ of these elements showed injury discharges with a sudden shift of potential to negativity. In the absence of injury discharges the negative potential may represent resting potentials recorded from glial elements ( $\mathrm{Li}, 1955$ and 1959). At temperatures 


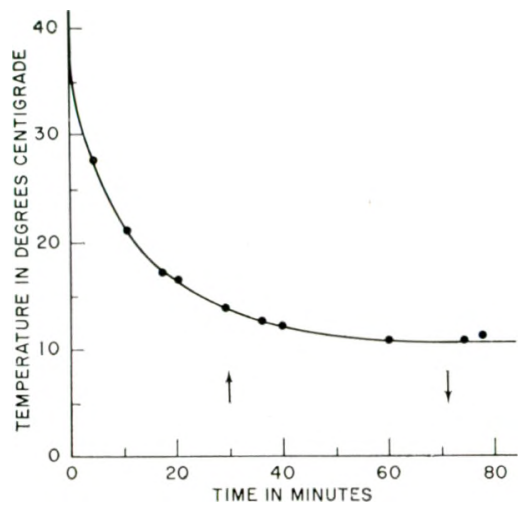

Fig. 1. Time course of change in brain temperature under extracorporeal hypothermia. Arrows indicate beginning and end of ventricular perfusion.

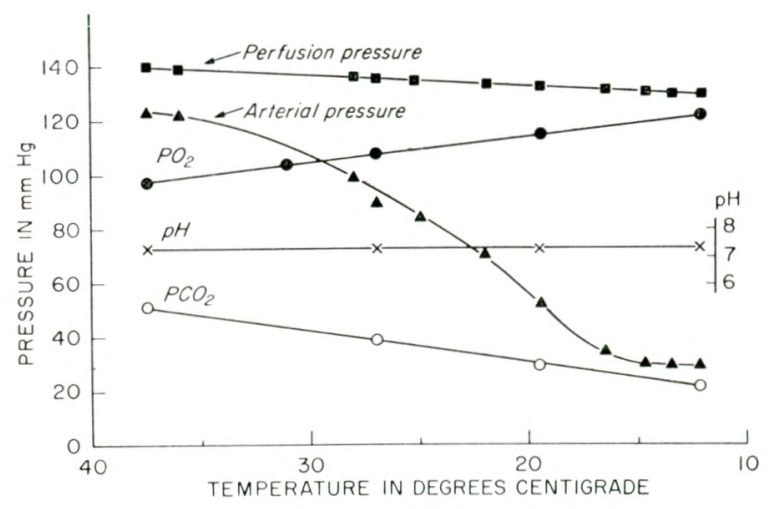

Fig. 2. Perfusion pressure, blood pressure, $P_{\mathrm{O}_{2}}, P_{\mathrm{CO}_{2}}$ and $\mathrm{pH}$ measurements at various brain temperatures.

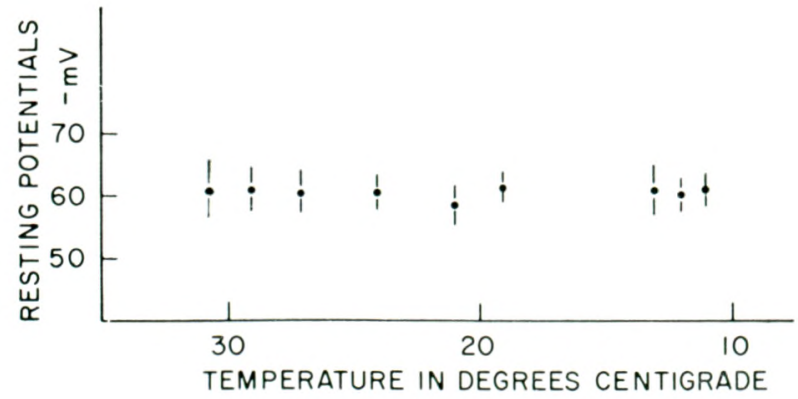

Fig. 3. Resting membrane potentials of 87 polarized cortical elements at various brain temperatures. 


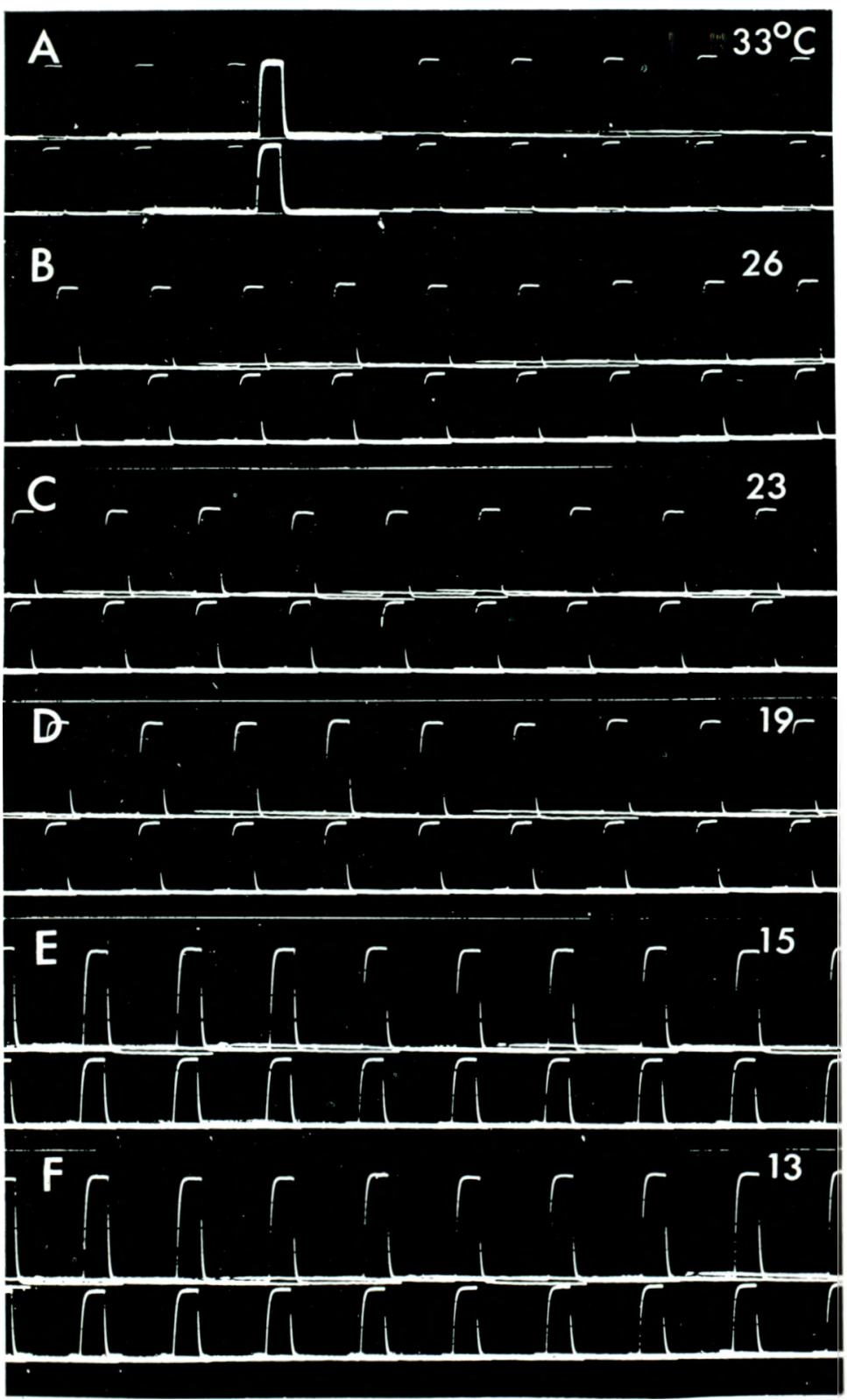

Fig. 4. Impedance changes simultaneously recorded from the grey matter (first tracing) and white matter (second tracing) at various brain temperatures (indicated at right upper corner of each record)

below $17^{\circ} \mathrm{C}$, none of the penetrated elements showed injury discharges. The mean value and the standard deviation of these measurements are shown in Fig. 3. Since there is no way of identifying neurons from neuroglia by electrophysiological methods at low temperatures, the values given in Fig. 3 must represent the mean values from References p. 396 


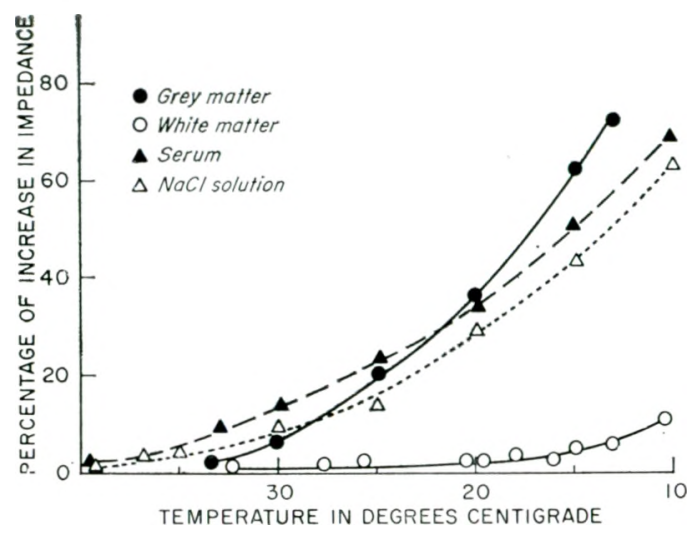

Fig. 5. Impedance changes of the grey matter, white matter, blood serum and $\mathrm{NaCl}$ solution.

all polarized elements in the cortex. It follows that no change in the resting potential occurs in these polarized elements at temperatures between 30 and $11^{\circ} \mathrm{C}$.

Impedance changes recorded at low temperatures consistently revealed a discrepancy in the measurements from the grey matter and white matter. An example' is given in Fig. 4, which shows a gradual increase in the electric resistivity of the cortex and little or no change in the white matter when the temperature of the hemisphere was lowered from 33 to $13^{\circ} \mathrm{C}$. These measurements of impedance changes obtained from each experiment were converted into proportional values and the average values at a given temperature obtained from all experiments were plotted in Fig. 5. It can be seen that in the white matter there is very little change in the impedance at temperatures above $20 \mathrm{C}$; and a gradual increase to $10 \%$ at temperatures between 20 and $10^{\circ} \mathrm{C}$. This is in contrast with the findings from the grey matter from which an increase of over $60 \%$ at $15^{\circ} \mathrm{C}$ and $70 \%$ at $12.6^{\circ} \mathrm{C}$ were recorded.

Fig. 5 also shows the average values of impedance measurements recorded from cat's serum and $\mathrm{NaCl}$ solution. At temperatures above $20^{\circ} \mathrm{C}$, these values are comparable to those recorded from the grey matter; but below $20^{\circ} \mathrm{C}$ they are significantly smaller. It also shows that these values are much higher than those recorded from the white matter throughout the entire range of temperatures tested.

The penetration of various substances from the ventricles into the surrounding parenchyma revealed the following features.

In animals subjected to selective cooling of the brain sodium fluorescein, $\left[{ }^{14} \mathrm{C}\right]-$ inulin and $\left[{ }^{14} \mathrm{C}\right]$ sucrose showed a striking reduction of periventricular spreading in comparison with cats perfused with these substances at normal temperature. On the other hand, the effect of hypothermia on the passage of $\left[{ }^{14} \mathrm{C}\right] \mathrm{L}$-leucine appeared to be rather insignificant. At normal temperatures all indicators extended for approximately 3-4 mm into the putamen, whereas the spread into the corpus callosum seemed to be more limited (Fig. 6a, b). At lower brain temperatures the reduction in penetration of the first three indicators was very conspicuous, and was usually more pronounced in the putamen where only a narrow rim of subependymal tissue showed the presence of 

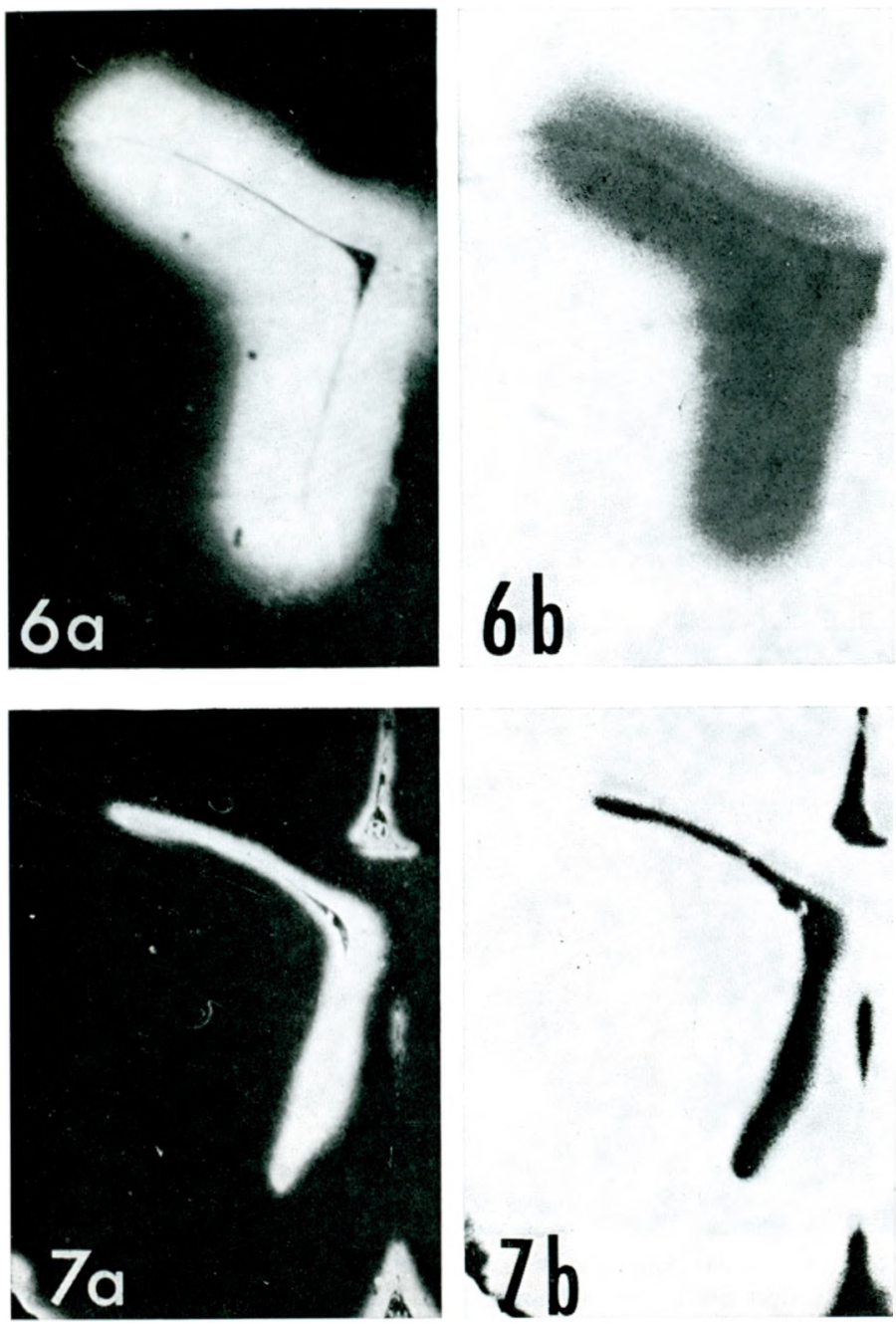

Fig. 6. (a) Cat subjected to ventriculo-cisternal perfusion with sodium fluorescein and $\left[{ }^{14} \mathrm{C}\right]$ inulin at the normal temperature. The $10 \mu$ section photographed under the U.V. light. The fluorescence of sodium fluorescein is seen extending into brain tissue adjacent to the lateral ventricle; (b) Radioautograph showing the distribution of $\left[{ }^{44} \mathrm{C}\right]$ inulin on the same section.

Fig. 7. (a) Ventriculo-cis ernal perfusion with sodium fluorescein and $\left[{ }^{14} \mathrm{C}\right]$ inulin at $13^{\circ} \mathrm{C}$. The same anatomical level as in Fig. 6. The penetration of sodium fluorescein from the lateral ventricle is very restricted, especially into the putamen; (b) Radioautograph showing the passage of $\left[{ }^{14} \mathrm{C}\right]$ inulin on the same section.

the tracer (Fig. 7a, b). Although it appeared that the passage of $\left[{ }^{14} \mathrm{C}\right] \mathrm{L}$-leucine was also affected by lowering the temperature the reduction was small and sometimes even difficult to ascertain (Figs. 8, 9).

Electron microscopy revealed no major abnormality in either normothermic or hypothermic brain. Preservation of tissue was adequate. An occasional pyknotic neuron was seen, but in general nerve cells were not abnormal. Definite astrocyte 

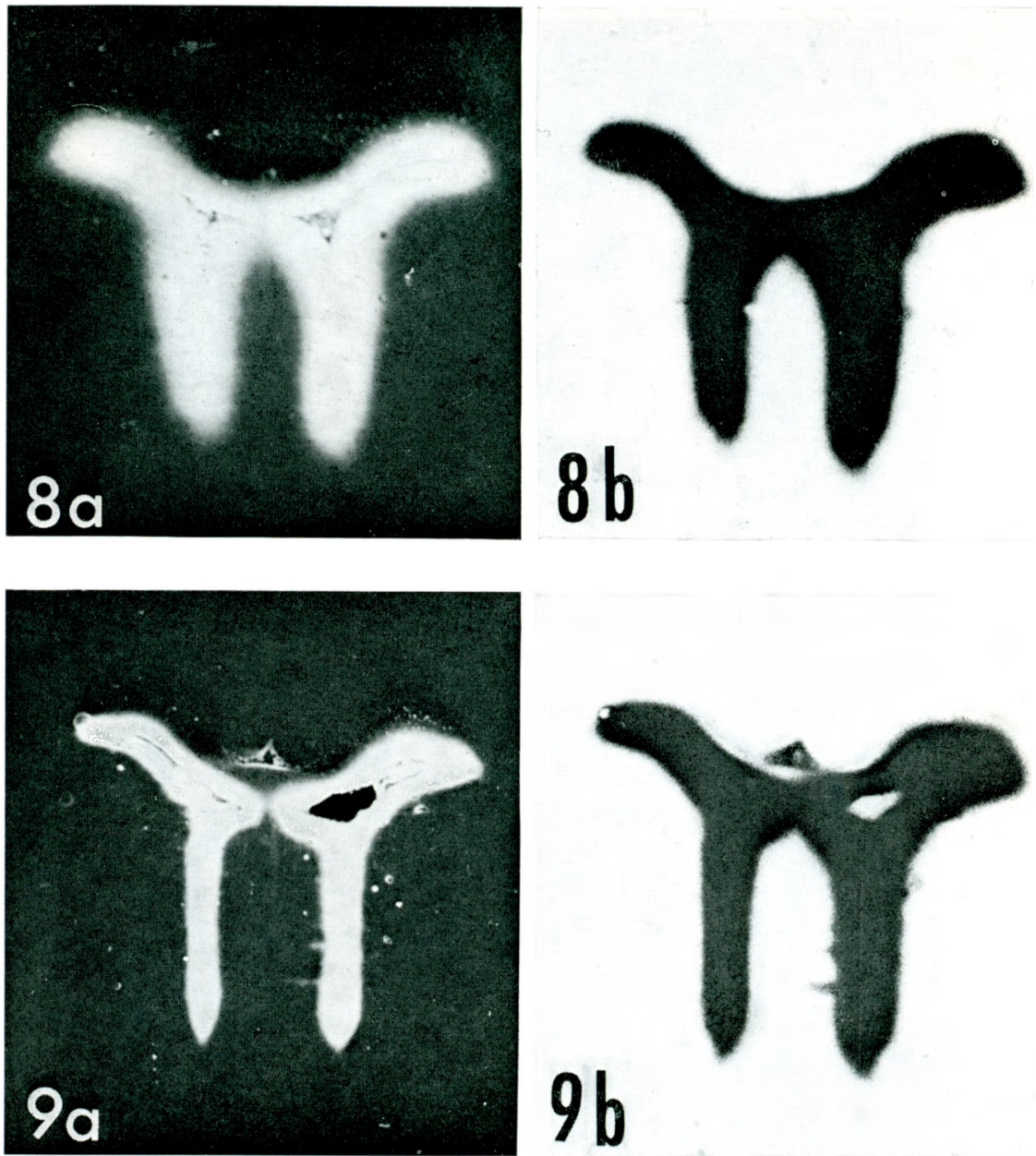

Fig. 8. (a) Ventriculo-cisternal perfusion with sodium fluorescein and $\left[{ }^{14} \mathrm{C}\right] \mathrm{L}$-leucine at the normal temperature. This section photographed under the U.V. light shows the distribution of sodium fluorescein; (b) Radioautograph showing the periventricular penetration of $\left.{ }^{14} \mathrm{C}\right] \mathrm{L}-$ leucine on the same section.

Fig. 9. (a) Ventriculo-cisternal perfusion with sodium fluorescein and $\left[{ }^{14} \mathrm{C}\right] \mathrm{L}$-leucine at $14^{\circ} \mathrm{C}$. Fluorescent photograph shows the reduction in passage of sodium fluorescein as compared with that at the normal tempcrature; (b) Radioautograph of the section shown in 9 a. The reduction of L-leucine passage into periventricular brain tissue appears to be insignificant when compared with Fig. $8 \mathrm{~b}$ of a cat perfused at the normal temperature.

swelling or shrinkage was not seen, and there were no major changes in the extracellular space in grey or white matter (Fig. 10). There were no obvious differences between the two groups. These preliminary observations are not complete, however, and measurement analysis has not been applied to the tissue. While inspection reveals no obvious abnormalities which might explain the observed phenomena, it is not possible to compare exactly cellular, process, and space sizes in the two groups until quantification is complete. 


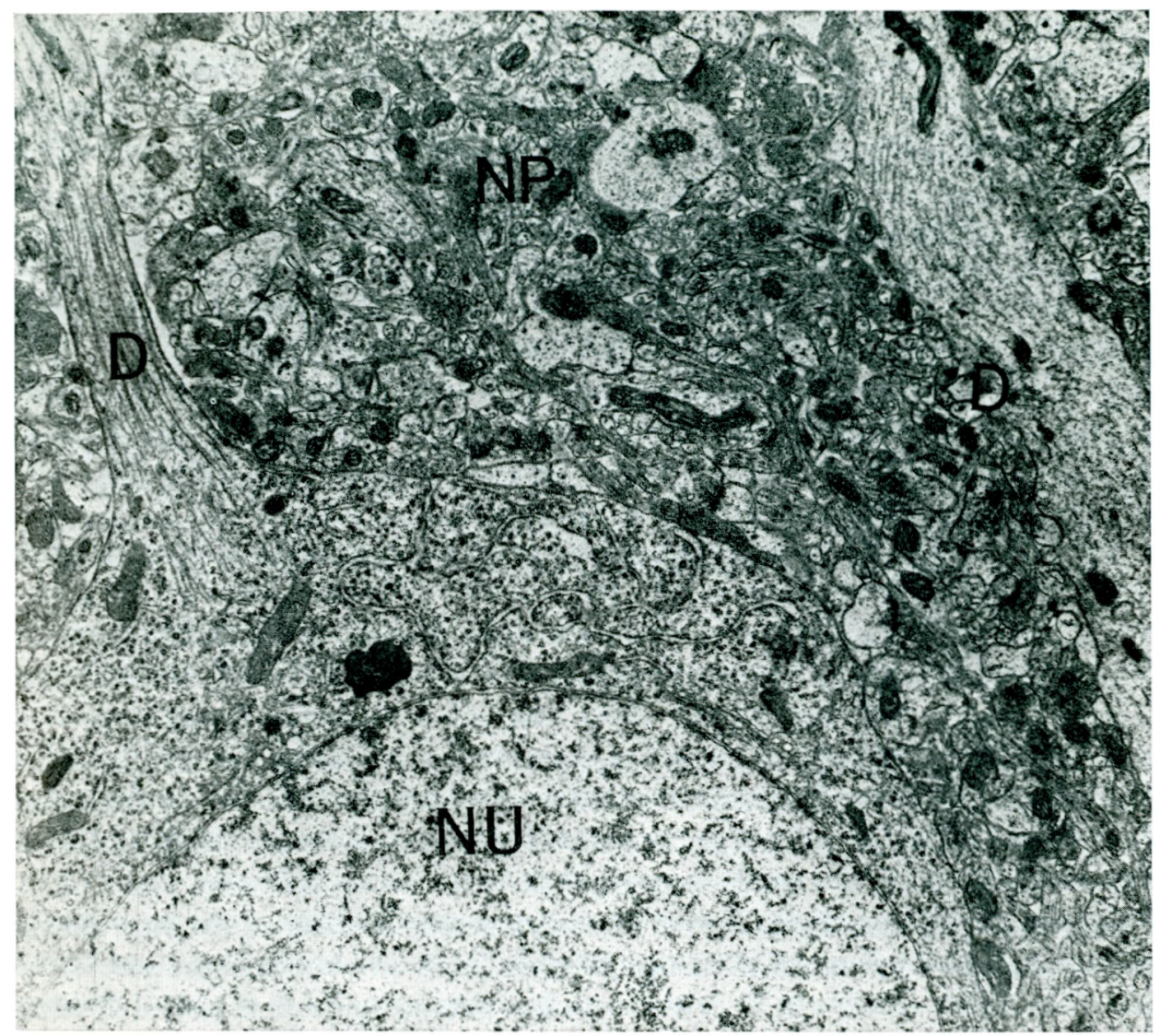

Fig. 10. Cat caudate nucleus fixed at $12^{\circ} \mathrm{C}$ by perfusion with $2.5 \%$ glutaraldehyde in $\mathrm{PO}$ buffer. A normal appearing neuron (NU) with a dendrite (D) are shown. Another dendrite (D, right) crosses the field. No dramatic change in dendrite size. Cellular elements of neuropil (NP) and extracellular space do not appear different than normal. $\times 10300$.

DISCUSSION

Under normal brain temperature, the electric current applied to the brain for measurement of impedance changes is primarily carried by electrolytes in the extracellular space. From experiments on circulatory arrest (Van Harreveld and Ochs, 1956), it was estimated that the blood, which flows through the brain tissue, is responsible for about $11 \%$ of the total conductivity of the brain. The cellular elements contribute little or none to the change in brain conductivity owing to the high resistance of their limiting membrane.

In the present investigation, impedance changes recorded from the grey matter at temperatures above $20^{\circ} \mathrm{C}$ were found to be comparable to those recorded from $\mathrm{NaCl}$ solution and blood serum. This can be attributed to the temperature coefficient of the electrolyte fluid in the extracellular space, which is in complete agreement with 
Collewijn and Schade $(1962,1964)$. However, at temperatures below $20 \mathrm{C}$ the impedance changes of the grey matter became greater than those recorded from $\mathrm{NaCl}$ solution and serum, suggesting that impedance changes of the grey matter at temperatures below $20 \mathrm{C}$ are not entirely determined by temperature coefficient of the extracellular fluid.

One may argue that the excessive increase of grey matter impedance is due to a decrease in extracellular space as a result of an increase in the volume of the cell (Van Harreveld et al., 1965). It was shown (Reulen et al., 1966) that a significant increase in the uptake of sodium and water in brain tissue occurred at temperatures below $10^{\circ} \mathrm{C}$. Above $10^{\circ} \mathrm{C}$ there was no significant increase. It is also known that cells in brain become swollen in experimental animals under asphyxia (Van Harreveld, 1957). In the present investigation the brain temperature was reduced, but not below $11^{\circ} \mathrm{C}$; and, in all instances, there was no indication of hypoxia.

The measurements of resting membrane potential are comparable to those recorded from cortex of normothermic cats ( $\mathrm{Li}, 1955$ and 1959) and brain slices of the guinea pigs (Li and McIlwain, 1957). The consistent values obtained at low temperatures are in agreement with the findings from single skeletal muscles of the hypothermic frogs ( $\mathrm{Li}$ and Gouras, 1958) and rats ( $\mathrm{Li}, 1958)$. The lack of change in resting membrane potential indicates not only an absence of disturbance in the differential distribution of ions between the extracellular and intracellular compartments but also an absence of excessive accumulation of water in the tissue. The indication that cell swelling did not occur is supported by the preliminary findings from electron microscopy.

Despite the regulated blood flow in the common carotid artery of our experimental animal, the actual volume of blood circulating in the cooled hemisphere is not known and this variable remains to be determined. In experiments ( $\mathrm{Li}$ et al., 1966) designed for the study of systemic blood pressure and brain impedance changes, it was found that the lower the blood pressure the lower is the tissue impedance. This observation implies that the impedance change of the grey matter at temperatures below $20^{\circ} \mathrm{C}$ should be lower than the change caused by the temperature coefficient of the extracellular fluid alone; but this is not the case.

The above arguments leave an alternative that at temperatures below $20^{\circ} \mathrm{C}$, the increased impedance recorded from the grey matter is due to a decrease of the extracellular space. This suggestion, however, cannot be applied to the changes recorded from the white matter of the brain.

The conspicuous inhibition of the passage of sodium fluorescein, inulin, and sucrose may well be related to a reduction in extracellular space. The distribution of these tracers (especially the last two) is generally believed to be extracellular. Restriction of the space available for migration should inhibit their rate and extent of spread.

Since temperature has a direct influence upon rate of diffusion, the inhibition of migration of inulin in our study was compared with the inhibition to be expected if the effect was simply one of temperature reduction on diffusion. The quantitative technique of Rall et al., (1962) was utilized for us by Dr. Fenstermaker of that laboratory. Preliminary results indicate the reduction in inulin migration from the ventricular surface 
markedly exceeds the predicted reduction if the results were related to temperature coefficients alone. Reduction of the extracellular space available for diffusion is a plausible explanation of this discrepancy.

We expected that hypothermia would have a definite effect upon the active transport mechanism which supposedly is responsible for the movement of L-leucine from the CSF. While the results were not unequivocal, the reduction in passage of L-leucine was small at best, and difficult to ascertain. This is unexplained, and additional study of this phenomenon is planned.

The ultrastructural analysis of the tissue is not complete. However, it can be stated that no obvious tissue damage or large differential increase or decrease in any tissue element occurred. It is entirely possible that exact measurements may reveal a significant change in some volume component, however. This possibility cannot be fully evaluated until measurements are complete. At least there is no serious cellular damage or destruction of tissue which should markedly influence the results.

\section{SUM MAR Y}

Study of impedance changes and resting membrane potentials as well as the rate of passage of various substances from the cerebral ventricles to the brain tissue in hypothermic cats has led to the following results and suggestions:

1. At brain temperatures above $20^{\circ} \mathrm{C}$, impedance changes recorded from the grey matter were comparable with those recorded from blood serum and $\mathrm{NaCl}$ solution at corresponding temperatures. This can be attributed to temperature coefficient of the electrolyte fluid in the extracellular space.

2. At temperatures below $20^{\circ} \mathrm{C}$, impedance changes recorded from the grey matter became greater than those from serum and $\mathrm{NaCl}$ solution. It is suggested that at these low temperatures there is a reduction of the extracellular space.

3. At temperatures above $12^{\circ} \mathrm{C}$, there was no indication of hypoxia and'no change in the resting membrane potential of the cellular elements in the cerebral cortex. These findings imply that swelling of cells and disturbance of differential distribution of ions did not occur at these low temperatures.

4. Impedance changes recorded from the white matter were much smaller than those recorded from the grey matter. The mechanism by which this discrepancy exists remains to be determined.

5. Using fluorescence and radioautography the effect of lowering the brain temperature on periventricular passage from CSF was assessed with regard to sodium fluorescein, $\left[{ }^{14} \mathrm{C}\right]$ inulin, $\left[{ }^{14} \mathrm{C}\right]$ sucrose and $\left[{ }^{14} \mathrm{C}\right] \mathrm{L}$-leucine. Sodium fluorescein, $\left[{ }^{14} \mathrm{C}\right]$ inulin and $\left[{ }^{14} \mathrm{C}\right]$ sucrose showed a marked reduction of periventricular passage at $15-12^{\circ} \mathrm{C}$, whereas only a small effect was observed with regard to $\left[{ }^{14} \mathrm{C}\right] \mathrm{L}-$ leucine.

6. These data indicate the possibility that at $15-12^{\circ} \mathrm{C}$ there is a reduction in extracellular compartment without appreciable shift in electrolytes which may account for the increased impedance values in the grey matter and for the observed reduction in pasage of the mentioned compounds.

References p. 396 


\section{REFERENCES}

Brendel, W., Muller, Ch., Reulen, H. J. and Messmer, K. (1966) Elektrolytveränderungen in tiefer Hypothermie. II. Beziehungen zur klinischen und biologischen Überlebenzeit. Pfirgers Archiv, 228. 220-238.

Collewijn, H. And Schadé, J. P. (1962) Cerebral Impedance Changes in Hypothermia. Arch. Intern. Physiol. Biochem., 70, 200-210.

-, (1964) Chloride, Potassium and Water Content of Apical Dendrites and Their Changes after Circulatory Arrest at Body Temperatures from $37^{\circ} \mathrm{C}$ to $20 \mathrm{C}$. Arch. Intern. Physiol. Biochem., 72, 194-210.

--, (1964) Conductivity of the Cerebral Cortex after Circulatory Arrest from $37^{\circ} \mathrm{C}$ to $18^{\circ} \mathrm{C}$. Arch. Intern. Physiol. Biochem., 72, 181-193.

Davson, H. and Spaziani, E. (1962) Effect of Hypothermia on Certain Aspects of the Cerebrospinal Fluid. Expt. Neurol., 6, 118-129.

Draskoci, M. Feldberg, W., Fleischauer, K. and Haranath, P. S. R. (1960) Absorption of Histamine into the Blood Stream on Perfusion of the Cerebral Ventricles and its Uptake by Brain Tissue. J. Physiol., 150, 50-72.

Klatzo, I., Miguel, J., Ferris, P. J., Prokop, J. O. And Smith, D. E. (1964) Observations on the Passage of the Fluorescein Labeled Serum Proteins from the Cerebrospinal Fluid. J. Neuropathol. Exptl. Neurol., 23, 18-35.

Kristiansen, K., Krog, J. And Lund, I. (1960) Experiences with Selective Cooling of the Brain. Acta Chirurg. Scand. Suppl., 253, 151-161.

Lajtha, A. (1962) Amino Acid Transport in the Brain. In: Properties of Membranes and Diseases of the Nervous System. M. D. Yahr (Ed.). Springer Publishing Co., New York, pp. 43-54.

Levin, E., Nogueira, G. J. and Garcia Argiz, C. A. (1966) Ventriculo-Cisternal Perfusion of Amine Acids in Cat Brain. $J$. Neurochem., 13, 761-767.

L, C. L. (1955) Action and Resting Potentials of Cortical Neurones. J. Physiol., 130, 96-108.

-, (1958) Effect of Cooling on Neuromuscular Transmission in the Rat. Amer. J. Physiol., 194, 200-206.

-, (1959) Cortical Intracellular Potentials and Their Response to Strychnine. J. Neurophysiol., 22, 4.36-450.

Li, C. L., Bak, A. F. And Parker, L. O. (1966) Some Electrophysiological Changes in the Brain under Hypothermia. (In preparation).

L1, C. L. AND Gouras, P. (1958) Effect of Cooling on Neuromuscular Transmission in the Frog. Amer. J. Phisiol., 192, 464-470.

Li, C. L. AND MCIlwain, H. (1957) Maintenance of Resting Membrane Potentials in Slices of Mammalian Cerebral Cortex and Other Tissues In Vitro. J. Physiol., 139, 178-190.

Ohta, T., Parker, L. O. And Li, C. L. (1966) The Perfusion Pressure in Hemicooling of the Brain. (In preparation).

Rall, D. P., Oppelt, W. W. and Patlak, C. F. (1962) Extracellular Space of Brain as Determined by Diffusion of Inulin from the Ventricular System. Life Sci., 2, 43-48.

Reulen, H. J., Aigner, P., Brendel, W., And Messmer, K. (1966) Elektrolytenveränderungen in tiefer Hypothermie. I. Die Wirkung akuter Auskühlung bis $0 \mathrm{C}$ und Wiedererwärmung. Pflïgers Arch., 228, 197-219.

Steinwall, O. And Klatzo, I. (1966) Selective Vulnerability of the Blood-Brain Barrier in Chemically Induced Lesions. J. Neuropathol. Exptl. Netrol., 25, 542-559.

Van Harreveld, A. (1957) Changes in Volume of Cortical Neuronal Elements During Asphyxiation. Amer. J. Physiol., 191, 233-242.

Van Harreveld, A., Crowell, J. and Malhotra, S. K. (1965) A study of Extracellular Space in Central Nervous Tissue by Freeze-Substitution. J. Cell Biol., 25, 117-137.

VAN Harreveld, A., ANd Ochs S. (1956) Cerebral Impedance Changes after Circulatory Arrest. Amer. J. Physiol., 189, 180-192. 